\title{
DWIFUNGSI TNI DARI MASA KE MASA
}

\author{
Asrudin Azwar ${ }^{1}$ \\ Mirza Jaka Suryana ${ }^{2}$ \\ Peneliti dan Pendiri The Asrudian Center. ${ }^{1}$ \\ Mahasiswa Pascasarjana Ilmu Politik Universitas Nasional, Jakarta. ${ }^{2}$
}

\begin{abstract}
Abstrak
Dwifungsi angkatan bersenjata di Indonesia berevolusi dan mencapai puncaknya pada era Orba. Di era ini peran sosial-politik ABRI menjadi sangat dominan dalam segala aspek kehidupan masyarakat. Namun setelah rezim Orba runtuh pada 1998, dengan krisis moneter akut yang menyertainya, masyarakat Indonesia menuntut negara ini menjadi demokratis seutuhnya. Akibatnya, Dwifungsi ABRI pun ditinggalkan. Tapi seiring berjalannya waktu, upaya untuk mengembalikan Dwifungsi tetaplah kuat. Kini jenderal-jenderal TNI bahkan sudah mulai mengisi berbagai jabatan sipil. Ini tentu saja merupakan langkah mundur dan membuat Indonesia seakan kembali ke masa otoriter. Rencana pemerintahan Jokowi untuk memberikan ruang jabatan bagi militer di kementerian dan institusi sipil lainnya bertentangan dengan semangat demokrasi dan jika dibiarkan akan menjurus kepada sikap otoritarianisme.
\end{abstract}

Kata kunci: Pemerintahan Jokowi, Dwifungsi, ABRI, militer, otoriterianisme, peran sosial, peran politik, jabatan sipil

\begin{abstract}
Dwifungsi (dual-function) of the Indonesian Arm Forces has been evolved and reached its peak in the New Order era. The social and political role of Indonesian Arm Forces became dominant in every aspects of the life of society. After the regime downfall in 1998, with the monetary crisis which accompanied it, Indonesian civil society demanded the state to be fully democratic. Thus, the Dwifungsi is left behind. Nevertheless, the effort to restore Dwifungsi is still strong. By now, many of Indonesian military generals has occupies public offices. It is of course a backward and making Indonesia to its darker past. The plan of Jokowi's administration to give posts for military officers in ministries and civil institutions is not accord with democratic spirit and tend to bring back authoritarianism to life.
\end{abstract}

Keywords: Jokowi administration, Dwifungsi, Dual-function, ABRI, military, authoritarianism, social roles, political roles, civil offices 


\section{PENDAHULUAN}

Suka atau tidak, militer tidak bisa dilepaskan dari sejarah berdirinya negara Indonesia. Itu artinya, secara informal militer juga memiliki peran penting dalam mencapai kemerdekaan negara dan juga perkembangan Indonesia selanjutnya. TNI, dengan kata lain, ikut serta dalam pembuatan dan pembangunan negara. Dari pengalamannya dalam proses pembuatan dan pembangunan negara inilah yang kemudian membentuk persepsi ancaman dan basis ideologis bagi TNI untuk terlibat secara aktif dalam kehidupan sosial-politik Indonesia.

Dalam karya analitiknya The Army and Politics in Indonesia, Harold Crouch mencatat bahwa militer Indonesia, sejak awal berdirinya, tidak pernah menganggap diri mereka sebagai instrumen negara yang peduli dengan masalah keamanan. ${ }^{3}$ Sebaliknya, TNI selalu menganggap dirinya sendiri sebagai "kekuatan militer" dan "kekuatan sosial-politik Indonesia." Orde Baru (Orba) kemudian melembagakan basis ideologis TNI ini. Dari sini kita bisa menyaksikan bagaimana TNI berhasil mendominasi politik Indonesia selama lebih dari tiga dekade (19661998).

Namun setelah itu situasi politik berubah. TNI disapu gelombang reformasi 1998. Di tengah berbagai tekanan publik dan oposisi, dan diperparah oleh krisis ekonomi akut, Soeharto, yang menjadi rezim otoriter selama 32 tahun, akhirnya dipaksa mundur pada Mei 1998. TNI - yang selama ini mendapat keistimewaan politik dari Soeharto - kemudian meninggalkan pelindungnya itu dan bersama dengan kekuatan-kekuatan demokratis lain-nya menyaksikan bagaimana Soeharto dicopot secara memalukan.

Setelah Soeharto lengser, penggantinya Presiden BJ Habibie mengizinkan militer untuk mereformasi dirinya. Dengan izin itu, militer kemudian berniat menghapus Dwifungsi ABRI. Wiranto dan jenderal-jenderal yang berpikiran reformis merancang konsep Baru bagi militer, yang akan memandu pengurangan peran politik militer dalam kehidupan politik Indonesia. Untuk itu, sejumlah

\footnotetext{
${ }^{3}$ Lihat Harold A. Crouch, The Army and Politics in Indonesia, (Itacha: Cornell University Press, 1978); Untuk edisi terjemahannya lihat Harold A. Crouch, Militer dan politik di Indonesia, (Jakarta: Sinar Harapan, 1986)
} 
restrukturisasi organisasi dilakukan oleh militer, termasuk likuidasi struktur sosiopolitik TNI dan kekaryaan (penugasan militer) personil untuk posisi pemerintah non-militer; pemisahan polisi dari militer; dan penarikan dukungan resmi militer terhadap Golkar, partai yang berkuasa selama rezim Orba. Jatah kursi di parlemen juga dikurangi saat pemilihan umum pertama pasca-Orba tahun 1999, sampai akhirnya ditarik sepenuhnya dari parlemen pada 2004. Lalu bagaimana kelanjutan dari reformasi militer di Indonesia?

Artikel ini kami tulis untuk menjawab pertanyaan tersebut dengan menelusuri sejarah Dwifungsi TNI dari masa ke masa. Untuk memenuhi tujuan itu, pertama-tama kami akan membahas terlebih dahulu sejarah tentang bagaimana militer dibentuk, lalu mengupas bagaimana militer bisa ikut serta dalam kehidupan politik Indonesia, kemudian menguraikan bagaimana militer bisa memutuskan untuk melakukan reformasi atas tubuhnya sendiri, dan sesudah itu apakah peran politik militer berhasil dihapuskan dalam kehidupan politik Indonesia.

\section{PEMBAHASAN}

\section{A. Pembentukan ABRI}

Secara formal, sebelum Proklamasi Kemerdekaan, Indonesia belum memiliki Angkatan Bersenjata, sehingga peran Angkatan Bersenjata Republik Indonesia di masa depan menjadi sangat penting. Ada dua pendekatan berbeda dalam kaitan dengan tercapainya kemerdekaan. Pemerintah dan para politisi sipil percaya bahwa kemerdekaan dapat dicapai dengan jalan diplomasi. Angkatan bersenjata dan Pemuda percaya kemerdekaan seharusnya diraih melalui perjuangan bersenjata. Posisi berbeda antara pemerintah dan ABRI ini menandai hubungan antara ABRI dan masyarakat, serta ABRI dan pemerintah di dalam negara Republik Indonesia. $^{4}$

Barisan Keamanan Rakyat (BKR) didirikan pada tanggal 20 Agustus 1945 dan kebanyakan anggotanya berasal dari PETA dan Heiho. BKR sendiri bukanlah angkatan bersenjata melainkan suatu lembaga untuk memberikan perlindungan

\footnotetext{
${ }^{4}$ Lihat Soedibyo, "Armed Forces of the Republic of Indonesia: Prospects for the 1990s", dalam The Indonesian Quarterly, Vol. 18, No. 3 (Kwartal ke-3, 1990), hal. 223.
} 
keamanan pribadi maupun harta rakyat. Polisi Negara juga didirikan untuk mempertahankan hukum dan ketertiban setempat. Akan tetapi, banyak kelompok bersenjata merasa keberatan terhadap hal ini dan mulai mendirikan organisasiorganisasi perjuangan mandiri seperti Angkatan Muda Republik Indonesia dan Barisan Pemberontakan Rakyat Indonesia. Banyak Tentara Pelajar juga dibentuk selama periode ini. $^{5}$

Satu setengah bulan setelah proklamasi kemerdekaan, pemerintah menyadari bahwa pemerintahan tidak bisa berjalan tanpa angkatan bersenjata nasional. Hal ini sebagian disebabkan oleh merebaknya angkatan-angkatan bersenjata yang berdiri sendiri-sendiri di seluruh negeri, di samping hampir tibanya pasukan Sekutu di bawah kepemimpinan Inggris, yang dimaksudkan untuk memulihkan kolonialisme Belanda. Pada akhir September 1945, berbagai unit polisi diintegrasikan menjadi lembaga tunggal dengan penunjukan Kepala Polisi Nasional. Sebagai akibat dari situasi keamanan internal dan eksternal, pada tanggal 5 Oktober 1945, dengan otoritas Dekrit Presiden Nomor 10-1-1945, BKR diubah menjadi Tentara Keamanan Rakyat (TKR). Letjen Urip Sumohardjo, pensiunan perwira KNIL, diberi tanggungjawab untuk mempersatukan berbagai kelompok bersenjata dan sampai sekarang, 5 Oktober dirayakan sebagai Hari Kelahiran Angkatan Bersenjata Republik Indonesia.

Dalam dua minggu pembentukan TKR memiliki 10 divisi di Jawa dan 6 divisi di Sumatera, di samping banyak pasukan perlawanan lainnya di seluruh negeri, TKR bentrok dengan Angkatan Darat Sekutu (Gurkha-Inggris) yang mendarat di Surabaya, dan mulai memasukkan pasukan Netherlands Indies Civil Administration (NICA) ke Indonesia. Pertempuran pada tanggal 28 Oktober mengakibatkan terbunuhnya Jenderal Mallaby, komandan pasukan Sekutu. Penerusnya, Jenderal Mansergh, memberi ultimatum kepada rakyat Surabaya untuk menyerah. TKR juga bertempur melawan pasukan Sekutu di Magelang, Ambarawa dan Bandung. Jakarta sudah jatuh ke tangan Sekutu. Pertempuran hebat terjadi pada 5 Bilveer Singh, Dwifungsi ABRI: Asal-usul, Aktualisasi dan Implikasinya bagi Stabilitas dan
Pembangunan, (Jakarta: Gramedia Pustaka Utama, 1996), hal. 30. 
tanggal 10 November 1945, yang kemudian diperingati sebagai Hari Pahlawan Nasional.

Pertempuran-pertempuran dengan pasukan Sekutu menunjukkan perlunya koordinasi. Khawatir muncul kolonialisme baru, digelarlah konferensi semua angkatan bersenjata pada tanggal 11 November 1945, dipimpin oleh Urip. Sasaran utama konferensi adalah memeroleh dukungan dan kerjasama dari berbagai komandan lokal, terutama komandan-komandan yang tidak dibawah kendali TKR, di samping mengembangkan strategi umum untuk mempertahankan Republik terhadap Sekutu setelah pertempuran besar di Surabaya. Sebelum persetujuan bisa dicapai tentang soal-soal ini, keputusan historis dibuat oleh konferensi ini dengan memilih menteri pertahanan dan panglima besar. Sultan Hamengku Buwono IX ditunjuk sebagai Menteri Pertahanan, sementara Kolonel Sudirman, mantan komandan PETA yang karismatik, pada waktu itu menjadi komandan divisi ketiga di Banyumas, dipilih sebagai Panglima Besar. Mayor Urip dipilih kembali menjadi Kepala Staf. Sudirman dan Urip dipromosikan ke tingkat Letnan Jenderal. ${ }^{6}$

Syahrir, yang mengepalai dan membentuk pemerintahan parlementer di Jakarta tidak mengetahui konferensi para komandan di Yogyakarta itu, dan menunjuk Amir Syarifuddin sebagai menteri pertahanan. Hal ini membuat kekacauan dan friksi antara kepemimpinan militer di bawah Sudirman dan pemerintahan Syahrir. Pada tanggal 18 Desember 1945, Sukarno secara formal menunjuk Sudirman sebagai Panglima Besar Angkatan Bersenjata Republik Indonesia tetapi menolak untuk menunjuk Sultan sebagai menteri pertahanan. Dalam hal ini, secara tegas terlihat bahwa pemerintah tidak menunjuk pimpinan militer, tetapi kepemimpinan TKR terbentuk dari bawah dan dipaksakan untuk menduduki kepemimpinan politik. Hal ini merupakan tindakan politik penting, yang mempersatukan Angkatan 45 dengan satu misi demi mempertahankan negara dari dominasi asing. Menurut Bilveer Singh, penerimaan keputusan para komandan militer mengenai penunjukan Sudirman dipandang sebagai penerimaan pemerintah terhadap otonomi militer dalam politik Indonesia, dan dengan begitu membuat

${ }^{6} \mathrm{Ibid}$, hal. 32. 
kepemimpinan militer lebih percaya diri ketika sampai menyentuh hubungan sipilmiliter. $^{7}$

Pada 3 Juni 1947, Tentara Nasional Indonesia ditetapkan namanya. Mengikuti pembentukannya, selain ada banyak tantangan dari dalam struktur militer sendiri, TNI banyak diuji oleh ancaman terhadap republik yang datang dari berbagai sumber. Pertama, TNI terlibat dalam perang terbuka dengan Belanda setelah dua aksi polisionil mereka. Aksi pertama terjadi pada tanggal 21 Juli 1947 dan kedua terjadi pada 19 Desember 1948. Fakta bahwa aksi-aksi polisionil ini terjadi setelah politisi sipil mengadakan perjanjian dengan Belanda, Perjanjian Linggarjati (25 Maret 1947) dan Perjanjian Renville (17 Januari 1948), menimbulkan pertanyaan di kalangan pimpinan militer tentang efektivitas dan kecakapan para politisi maupun strategi diplomasi untuk merebut dan mengamankan kemerdekaan Republik Indonesia. Di samping pertempuran dengan Belanda, TNI juga memadamkan pemberontakan yang dilancarkan oleh Partai Komunis Indonesia pada tanggal 18 September 1948 di bawah pimpinan Muso.

\section{B. Dwifungsi ABRI}

Setelah menyoroti bagaimana ABRI dibentuk, $\operatorname{Singh}^{8}$ menegaskan bahwa ada empat perkembangan yang memengaruhi persepsi dan norma perilaku angkatan bersenjata Republik Indonesia. Pertama, fakta bawah ABRI menciptakan dirinya sendiri dan memandang dirinya sebagai pihak yang memiliki hak sama besar dengan kekuatan-kekuatan lain di negara ini, untuk ikut menentukan jalannya masyarakat. Kedua, fakta bahwa para Pemuda dan anggota angkatan bersenjata memandang diri mereka sendiri sebagai pejuang kemerdekaan yang telah ikut memperjuangkan kemerdekaan bagi negara. Kenyataan ini, khususnya pada waktu pemimpin politik siap menyerah, menegaskan bahwa militer dan pendekatan perjuangan senjata lebih kuat daripada pendekatan sipil dan diplomasi dalam memenangkan kemerdekaan dan kebebasan negara. Dengan begitu, muncul perasaan berhak atas keikutsertaan menentukan arah politik negara. Ketiga, fakta

\footnotetext{
${ }^{7}$ Ibid, hal. 33 .

${ }^{8}$ Ibid, hal. 45.
} 
bahwa para politisi sipil cenderung terpecah dan hanya mementingkan diri atau partainya sendiri, sementara angkatan bersenjata muncul sebagai kekuatan satusatunya yang tampak memiliki sifat nasional. Keempat, kenyataan bahwa Jenderal Sudirman, melalui tindakan dan sikap diamnya, mampu menarik garis dalam hubungan sipil-militer, bahkan sampai tidak mau ditundukkan. Kenyataan ini juga membentuk pikiran kaum militer bahwa mereka dapat menantang kepemimpinan politik ketika pemimpin politik tidak mampu atau tidak efektif dalam melindungi dan memajukan kepentingan nasional. Hal ini memberi jalan bagi hubungan sipilmiliter di Indonesia dan terus memengaruhi berbagai peristiwa dan arah pembangunan di negara ini. Dan dwifungsi ABRI harus dipahami dalam parameterparameter ini.

Konsep Dwifungsi ABRI sendiri sangat terkait dengan kelahiran dan peran angkatan bersenjata Republik Indonesia selama periode revolusioner dari bulan Agustus 1945 sampai Desember 1949. Konsep Dwifungsi juga berhubungan dengan pengalaman ABRI dan menjadi aktualisasi di masa depan. Dalam pandangan Harold Crouch, perasaan militer jelas mengungkapkan bahwa mereka ada sebelum Republik. "Kami ini Republik. Karena kami ada di sana waktu itu, orang-orang sipil bisa menyebut diri mereka menteri". ${ }^{9}$ Kaum militer beranggapan bahwa pada mulanya mereka pejuang kemerdekaan dan baru kemudian sebagai tentara. Oleh karena itu mereka memiliki hak politik yang sama sebagaimana kekuatan-kekuatan lain dalam masyarakat. Pertama-tama mereka bersifat "politis", dan baru kemudian "militer". ${ }^{10}$

Terbentuknya sikap angkatan bersenjata Indonesia, berbagai situasi yang melibatkan mereka, dan posisi para politisi sipil beserta lembaga-lembaganya yang pada umumnya lemah memberi kalangan militer Indonesia peluang untuk berperan besar dalam menentukan arah perpolitikan negara ini. Selama masa revolusi, rakyat memandang peran angkatan bersenjata penting, bahkan lebih penting dari peran kalangan politisi sipil, dalam mengejar tujuan bangsa yaitu kebebasan dan kemerdekaan. Hal ini menyebabkan pimpinan militer berani mengklaim bahwa

\footnotetext{
${ }^{9}$ Harold Crouch, Op.cit, hal. 25-26.

${ }^{10}$ Bilveer Singh, Op.cit, hal. 47.
} 
mereka juga memiliki hak berpolitik. Dwifungsi angkatan bersenjata Indonesia, yang pada dasarnya merujuk kepada peran angkatan bersenjata dalam masyarakat di luar lingkungan militer, dapat dipahami paling baik dengan melihat fase-fase sejarah modern di mana Dwifungsi diaktualisasikan di Indonesia.

Fase revolusioner sangat menentukan hubungan sipil-militer di Indonesia. Dua faktor yang saling berhubungan mengondisikan perkembangan ini, yaitu keterlibatan sejak awal pihak militer dalam politik dan kelemahan umum institusiinstitusi sipil. Sementara kaum nasionalis memilih diberlakukannya sebuah sistem presidensil setelah proklamasi kemerdekaan, pada tanggal 3 November 1945 Wakil Presiden Mohammad Hatta memperkenalkan sistem pemerintahan parlementer dengan mendorong dibentuknya partai-partai politik. Pada saat yang sama, karakteristik militer Indonesia juga membentuk kecenderungan kelompok ini untuk selalu melibatkan diri dalam politik. Militer Indonesia merupakan organisasi yang tidak dibentuk oleh pihak mana pun. Pada awalnya pemerintah sama sekali tidak berkeinginan membentuk angkatan bersenjata, kaum muda pada waktu itu mempersenjatai diri dan mulai bertindak sebagai sebuah kekuatan militer. Karena para politisi sipil yang membentuk pemerintahan tidak memberikan arah dan pedoman jelas bagi pihak militer, angkatan bersenjata harus memilih sendiri para pemimpinnya, termasuk panglima, sekaligus menjalankan kebijakan-kebijakan militernya sendiri. Jenderal Sudirman diangkat sebagai pemimpin angkatan bersenjata melalui pemilihan oleh para komandan militer. Baru di kemudian hari diakui oleh kalangan pemimpin politik. Sikap netral Jenderal Sudirman pada peristiwa 3 Juli 1946 ketika komandan Divisi Ketiga yang berkedudukan di Yogyakarta, dalam rangka membantu Tan Malaka beserta organisasi front bersatu melancarkan kudeta melawan pemerintahan Syahrir sampai terjadinya penculikan Syahrir membuat posisi jelas dari politik militer kala itu. Sudirman berada di luar konflik antara perdana menteri dan komandan divisi. Baru setelah Sukarno memerintahkan, ia mengambil tindakan mendukung pemerintah dan melawan Tan 
Malaka beserta organisasinya. Setelah peristiwa 3 Juli 1946 itu, Jenderal Sudirman merupakan salah satu faktor politik paling penting sampai akhir hayatnya. ${ }^{11}$

Meletusnya pemberontakan Madiun yang dipimpin PKI memperbesar kekuatan angkatan bersenjata. Ketika kabinet Amir Syarifuddin jatuh, Hatta membentuk kabinet presidensil. Langkah ini ditentang oleh kaum sosialis, yang di bawah kepemimpinan Amir membentuk Front Demokrasi Rakyat (FDR) pada tanggal 26 Februari 1948 untuk menentang Hatta beserta kebijakan-kebijakannya. Salah satu kebijakan utama Hatta yang ditolak adalah rasionalisasi dan restrukturisasi angkatan bersenjata. Sebagian besar partai sayap kiri, termasuk Partai Buruh dan Partai Sosialis, bersatu dengan PKI. Kepemimpinan kelompok ini ada di tangan Muso. Ketika pemberontakan bersenjata pecah di Madiun pada 18 September, TNI dengan cepat menumpas pemberontakan itu. Untuk pertama kalinya angkatan bersenjata mengorganisir diri secara besar-besaran demi menjalankan peran Dwifungsinya. Setelah berhasil menyelesaikan operasi keamanan, TNI mengambil alih fungsi-fungsi serta peran para pemimpin distrik (Kabupaten). Alasannya, mereka berusaha agar roda pemerintahan dan ekonomi tetap berputar sekaligus memulihkan stabilitas kehidupan sosial, juga menjalankan fungsi-fungsi keamanan yang mereka emban. Operasi-operasi Madiun ini memberi pengalaman nyata pertama dalam menjalankan peran militer sekaligus peran sosialpolitik mereka. ${ }^{12}$ Momentum serta pengalaman inilah yang juga ikut membentuk wawasan ABRI mengenai aktivitas-aktivitas semacam itu di kemudian hari.

Faktor penting lain adalah periode perang gerilya dari tanggal 4 Desember 1948 sampai 14 Agustus 1949. Di sini pihak militer mampu melaksanakan haknya sebagai kelompok militer sekaligus sebagai politisi. ${ }^{13}$ Sukarno dan Hatta hampir memutuskan menyerah kepada Belanda kala itu, tetapi Sudirman menentang dengan lari ke dalam hutan untuk melanjutkan perang gerilya. Sebelum Belanda menyerang Yogyakarta, Sudirman memerintahkan wakilnya, Nasution, untuk mempersiapkan wilayah ini sebagai ajang perang gerilya. Nasution melakukan

\footnotetext{
${ }^{11}$ Yahya A. Muhaimin, Perkembangan Militer dalam Politik di Indonesia, 1945-1966, (Yogyakarta: Gadjah Mada University Press, 1982), hal. 47.

12 Bilveer Singh, Op.cit, hal. 77.

${ }^{13}$ Ibid, hal. 78 .
} 
reorganisasi angkatan darat menjadi dua jenis angkatan yaitu tentara bergerak (mobile army) dan tentara teritorial. Nasution juga mempersiapkan wilayah ini untuk melakukan perang total. Tentara bergerak bertugas melakukan serangan terhadap musuh di mana pun berada, sementara tentara teritorial ditempatkan di sejumlah lokasi untuk bertindak sebagai inti perlawanan rakyat terhadap Belanda. Didirikannya Markas Komando Djawa, di mana Nasution menjadi komandannya, pada tanggal 18 Oktober 1948 membagi TNI ke dalam empat divisi dan diberi kekuasaan untuk menguasai Jawa. Sebagai komandan Tentara Jawa, Nasution merupakan pejabat tertinggi dan pemegang wewenang pemerintahan tertinggi selama keadaan darurat. Pada tanggal 2 Desember, Nasution mengumumkan penyelenggaraan pemerintahan militer di Jawa. Kemudian pada 24 Desember, ia mengeluarkan "Perintah Pelaksanaan untuk Pemerintahan Militer di Jawa" dengan menetapkan struktur pemerintahan militer di Jawa. Di bawah Nasution ada empat komandan divisi yang juga ditunjuk sebagai gubernur militer dari wilayah masingmasing. Di bawah komandan divisi ada komandan Sub Teritorium Militer (STM) yang setingkat residen sebagai kepala Keresidenan. Di bawah Keresidenan ada Kabupaten (distrik) yang setingkat dengan Komando Distrik Militer (KDM). Di bawahnya ada Kecamatan (sub-distrik) yang setingkat dengan Komando Order Distrik (KODM). Struktur ini menegaskan bahwa semua kepala pemerintahan sipil, dari gubernur sampai camat, ada di bawah para pejabat pemerintahan militer. Para pejabat sipil hanya bertindak sebagai penasihat saja bagi pejabat militer. ${ }^{14}$

Bagi pihak militer Indonesia, pengalaman perang gerilya menciptakan model perwujudan sipil-militer yang pada dasarnya memberi ciri pada kendali militer atas sistem politik di wilayah-wilayah yang tidak dikuasai Belanda. Apa yang diciptakan Nasution selama periode ini sebenarnya sistem pemerintahan paralel yang terbukti efektif dan fungsional. Pengalaman ini menentukan sikap pihak militer tentang bagaimana mereka harus berhubungan dengan orang-orang sipil. Pada akhir 1950an, model ini diaktifkan kembali, dan sejak tahun 1965 model ini sudah mengakar serta sudah diimplementasikan.

${ }^{14} \mathrm{Ibid}$, hal. $78-79$. 
Keputusan Sudirman untuk meneruskan perang gerilya melawan Belanda pada saat orang-orang sipil bersiap untuk menyerah, hanya dapat dipahami dengan mempertimbangkan lemahnya kepemimpinan sipil beserta lembaga-lembaganya. Para pemimpin sipil dinilai tidak mampu mengendalikan keterlibatan pihak militer yang semakin besar dalam kancah politik. Persaingan politik sipil yang membuat banyak perpecahan memperbesar keyakinan para pemimpin militer bahwa politisi tidak mampu memimpin revolusi, sehingga mereka merasa wajib menjalankan kebijakan-kebijakannya sendiri untuk membebaskan negara dari kolonialisme Belanda.

Setelah penyerahan kekuasaan pada Desember 1949 dan pembentukan Negara Kesatuan Republik Indonesia pada Agustus 1950, peran politik militer sangat dibatasi. Ada tiga alasan untuk pembatasan ini. Pertama, Undang-Undang Dasar Sementara 1950 didasarkan pada tradisi demokrasi liberal Barat yang dengan tegas menempatkan militer di bawah supremasi sipil. Kedua, angkatan darat ada di tangan kaum modernis. Ketiga, setelah Jenderal Sudirman meninggal pada Januari 1950, pihak militer kehilangan sosok pemimpin karismatik yang selalu siap menentang kepemimpinan politik setiap kali merasa bahwa militer diperlakukan secara tidak adil. ${ }^{15}$ Kehilangan sosok pemimpin karismatik merupakan tamparan besar dan perpecahan di tubuh kepemimpinan militer juga menyebabkan munculnya kekuatan sipil berhadapan dengan militer. Bersamaan dengan itu ada usaha besar untuk mentransformasikan angkatan bersenjata yang pada dasarnya revolusioner menjadi angkatan bersenjata yang profesional, meski nilai-nilai dari periode revolusioner tetap ditanamkan secara sistematis. ${ }^{16}$

Meski berbagai kondisi yang tampaknya melemahkan posisi politik militer, tidak berarti bahwa militer sama sekali menjadi apolitis. Keterlibatan dalam pengangkatan menteri pertahanan pada kabinet pertama Perdana Menteri Mohammad Natsir pada tahun 1950 membuktikan hal tersebut. Calon yang dijagokan Natsir akhirnya ditarik, digantikan oleh orang yang lebih dapat diterima

\footnotetext{
${ }^{15}$ Lihat Salim Said, Genesis of Power: General Sudirman and the Indonesian Military in Politics, 1945-49, (Singapore: Institute of Southeast Asian Studies, 1991), hal. 131-132.

${ }^{16}$ Bilveer Singh, Op.cit, hal. 82-83.
} 
kalangan militer. Dalam periode demokrasi liberal, ada dua peristiwa yang berpengaruh besar terhadap kepemimpinan militer-sipil dan kemudian membawa berbagai implikasi besar bagi peran militer dalam politik. Pertama peristiwa 17 Oktober 1952. Kedua, peristiwa Juni 1955. Peristiwa 17 Oktober 1952 menyebabkan Nasution didepak dari KSAD.

Pada 17 Februari 1955 dihasilkan piagam Jogjakarta, yang antara lain menyetujui promosi harus didasarkan pada senioritas. Piagama Jogjakarta menuntut adanya dikotomi yang jelas antara kepentingan sipil dan kepentingan militer, dalam sistem pemerintahan parlementer sekalipun. Penunjukan Kolonel Bambang Utoyo sebagai Kepala Staf baru oleh pemerintah pada tanggal 10 Juni 1955 dinilai menyimpang dari Piagam Jogjakarta yang telah dikomunikasikan kepada pemerintahan Ali Sastroamijoyo sebelum penunjukan itu dilakukan. Pada 27 Juni 1955 Kolonel Bambang, yang kemudian dipromosikan menjadi mayor jenderal, dilantik sebagai Kepala Staf yang baru. Tetapi peristiwa ini diboikot oleh pimpinan militer di bawah instruksi Pejabat Kepala Staf Angkatan Darat Zulkfili Lubis. Boikot ini kemudian dikenal sebagai "peristiwa Juni”, dan merupakan kegagalan pemerintahan Ali Sastroamijoyo. Sejak saat itu, angkatan bersenjata, khususnya angkatan darat, secara de facto menjadi kekuatan sosial politik yang aktif di negara ini. ${ }^{17}$

Kemudian pada 14 Maret 1957, pemerintahan Ali Sastroamijoyo jatuh, dan di hari yang sama undang-undang darurat perang diberlakukan secara nasional. Penyebab utama keadaan ini adalah merosotnya hubungan daerah-pusat, yang berujung pada pecahnya pemberontakan daerah oleh para komandan militer yang melahirkan pemberontakan PRRI/Permesta di Sumatera dan Sulawesi. Setelah dilantik kembali sebagai KSAD pada 1955, Nasution mulai melaksanakan doktrin untuk merasionalisasikan keterlibatan militer dalam politik. Nasution sangat percaya keterlibatan militer harus didasarkan pada hukum sehingga keterlibatan itu dinilai sah dan dapat diterima. Gambaran jelas pemikirannya baru muncul pada November 1958 ketika ia menyampaikan pidato bersejarah mengenai "Jalan

${ }^{17}$ Yahya Muhaimin, Op.cit, hal. 81. 
Tengah" di Akademi Militer Nasional, Magelang. Saat itu, para pejabat militer telah menduduki posisi di bidang-bidang yang secara tradisional dianggap sebagai wewenang sipil. Dengan alasan stabilitas serta persatuan, Nasution mengeluarkan seruan untuk membuang sistem demokrasi liberal. Alternatif satu-satunya demi kebutuhan itu adalah kembali ke UUD 1945. Menurut Nasution, Undang-Undang Dasar 1945 mengizinkan tiga bentuk wakil politik: partai politik, kelompok fungsional, dan utusan daerah. Menurut Nasution, angkatan bersenjata adalah kelompok fungsional yang penting. Sementara kelompok-kelompok lain mencakup para petani, artis, jurnalis, sarjana keagamaan, pekerja, kaum muda, perempuan dan intelektual. $^{18}$

Selain mendesakkan "jalan tengah” dan seruan kembali ke UUD 1945, Nasution menghidupkan kembali teorinya tentang perang gerilya dan manajemen teritorial yang pernah diterapkannya di Jawa sejak Desember 1948 sampai dengan Agustus 1949. Pada penghujung tahun 1958, Nasution memerintahkan Sekolah Staf dan Komando Angkatan Darat (SESKOAD) di Bandung untuk mempersiapkan doktrin militer yang akan memungkinkan pelaksanaan kebijakan "jalan tengah", berdasarkan pengalaman revolusi. Periode Demokrasi Terpimpin memberikan jalan bagi Nasution menerapkan banyak kebijakannya. Dengan begitu memberikan kuasa kepada militer untuk memainkan peran politik yang lebih besar lagi.

Pada 5 Juli 1959, secara resmi Sukarno mengembalikan negara ke UUD 1945 melalui Dekrit Presiden. Setelah berlakunya dekrit ini, keterlibatan militer beserta wakil-wakilnya dalam politik dan lembaga politik meluas dengan cepat. Ketika Sukarno mengumumkan Kabinet Kerja pada tanggal 10 Juli 1959, sepertiga menteri berasal dari militer. Nasution sendiri menjadi Menteri Pertahanan dan Keamanan. Ketika Sukarno mendirikan Dewan Perwakilan Rakyat Gotong Royong pada tahun 1960, 35 dari 283 anggotanya adalah ABRI. Setelah ini, Nasution untuk pertama kali menggunakan istilah "Dwifungsi”. Meski jarang digunakan, istilah ini kemudian diterima secara umum pasca Seminar Angkatan Darat Pertama tahun $1965 .^{19}$

\footnotetext{
${ }^{18}$ Lihat A.H. Nasution, Toward the People's Army, (Jakarta: C.V. Delegasi, 1964), hal. 20.

${ }^{19}$ Bilveer Singh, Op.cit, hal. 94.
} 
Militer pun bertumbuh semakin kuat dan hal ini memberi kekhawatiran bagi Sukarno. Guna mengimbangi kekuatan militer, Sukarno mereorganisasi undangundang darurat perang dengan menetapkan dirinya sebagai kepala Penguasa Perang Tertinggi (PEPERTI) dan semakin dekat dengan PKI. Pimpinan angkatan bersenjata, terutama Nasution, memandang semakin menguatnya pengaruh PKI sebagai ancaman bagi negara.

Setelah kudeta PKI yang menggemparkan dan mengakibatkan terbunuhnya enam pimpinan Angkatan Darat, termasuk Ahmad Yani, kepemimpinan Angkatan Darat diambil alih Suharto. Kejatuhan Sukarno mengawali era baru perpolitikan Indonesia di mana militer memiliki posisi paling kuat. Lewat Surat Perintah Sebelas Maret (Supersemar), 1966, Sukarno menyerahkan semua kekuasaan eksekutif kepada Suharto, dan pada Maret 1967 Sukarno dibebastugaskan. Suharto mengembangkan doktrin baru dengan meninggalkan "Jalan Tengah" Nasution demi prinsip di depan memberi teladan (ing ngarso sung tulodo), di mana ABRI harus memimpin dari depan.

Sementara Dwifungsi angkatan bersenjata telah disahkan pada Seminar Angkatan Darat Pertama tahun 1965, Seminar Angkatan Darat Kedua mengukuhkan Dwifungsi dan menghasilkan sejumlah terobosan penting yang secara resmi disahkan oleh MPRS 1966 ketika Resolusi 14 antara lain menyatakan bahwa "fungsi non-militer anggota ABRI, sebagai warga negara dan revolusioner yang pancasilais harus diakui dan dijamin kesinambungannya. ${ }^{20}$

Sejak 1966, fungsi sosial-politik angkatan bersenjata dilaksanakan melalui karyawan atau fungsionaris yang merupakan anggota angkatan bersenjata tetapi bertugas di luar kedinasan ABRI, baik di legislatif maupun eksekutif. Dwifungsi di era Orde Baru ini mengacu pada penggabungan fungsi umum ABRI sebagai kekuatan pertahanan dan fungsi kekaryaan ABRI. Pandangan ini segera dominan dalam masa setelah peristiwa GESTAPU/GESTOK karena dirasakan perlunya mengisi kekosongan yang terjadi akibat aksi pembersihan terhadap PKI di berbagai bidang kemasyarakatan, juga untuk memulihkan ketertiban setelah berbagai

${ }^{20}$ Salim Said, Op.cit., hal. 28. 
peristiwa yang mengguncang negara terjadi. ${ }^{21}$ Praktis, Dwifungsi ABRI menguasai seluruh aspek sosial politik bangsa di era Orba.

\section{Reformasi TNI}

Dwifungsi ABRI, sebagaimana dikupas di atas begitu mengakar pada era Soeharto. Namun setelah Soeharto lengser, situasi politik berubah. Peran TNI dalam politik Indonesia mulai dipertanyakan dan digugat melalui reformasi 1998. Saat reformasi bergulir, salah satu tuntutan keras yang disuarakan kelompok prodemokrasi adalah pencabutan Dwifungsi ABRI. Terpilihnya Abdurahman Wahid (Gus Dur) sebagai presiden membuat tuntutan itu cepat dikabulkan lewat sejumlah keputusan. Dalam masajabatannya yang sangat pendek (1999-2001), pemerintahan Gus Dur melakukan sejumlah reformasi TNI. Polri dipisahkan dari TNI. Doktrin Dwifungsi ABRI dicabut yang implementasinya melepaskan peran sosial-politik TNI. Militer aktif tidak lagi melibatkan diri dalam politik partisan untuk mendukung Golongan Karya. Fraksi TNI-Polri juga dihilangkan dari parlemen. Militer aktif tidak lagi menempati jabatan sipil.

Semangat itu awalnya ditunjukkan melalui sebuah seminar Angkatan Darat yang diadakan pada 22-24 September 1998. Ini adalah saat di mana Sekolah Staf dan Komando TNI di Bandung menyelenggarakan suatu seminar dengan mengangkat tema "Peran ABRI di Abad XXI". Tujuan dari seminar ini ialah untuk dilakukannya redefinisi, reposisi dan reaktualisasi peran ABRI dalam kehidupan bangsa. Seminar ini menghasilkan pemikiran yang dimaksudkan sebagai pegangan guna melakukan reformasi dalam tubuh TNI.

Dengan paradigma baru yang dihasilkan dari seminar tersebut, kalangan pimpinan TNI menjadi memiliki determinasi agar TNI kembali menjadi tentara yang profesional sebagai lembaga pertahanan negara yang tangguh dan kuat. Untuk maksud itu, maka Menteri Pertahanan dan Keamanan saat itu, Jenderal Wiranto yang dibantu oleh Kepala Staf Sosial Politik ABRI, Letnan Jenderal Susilo Bambang Yudhoyono dan pimpinan TNI lainnya, merasa perlu untuk mulai

${ }^{21}$ Bilveer Singh, Op.cit., hal. 110. Lihat juga Ulf Sundhaussen, Politik Militer Indonesia, 19451967: Menuju Dwifungsi ABRI, (Jakarta: LP3ES, 1987). 
mengurangi peranan TNI di dalam kehidupan politik, dan secara bertahap menarik diri dari kegiatan politik dan pemerintahan. Determinasi pimpinan TNI tersebut diaktualisasikan dalam bentuk kebijakan pimpinan TNI untuk mengurangi secara substansial jumlah personil TNI yang menjadi anggota DPR RI dan MPR RI. ${ }^{22}$

Kebijakan yang ditempuh pimpinan TNI pada masa Pemerintahan BJ.Habibie itu, kemudian dilanjutkan dengan "lebih bersemangat" oleh Pemerintahan Abdurrahman Wahid yang mencoba memberikan ruang lebih luas kepada kelompok sipil untuk lebih intensif memberikan sumbangannya dalam pembinaan pertahanan negara. Perkembangan proses pembinaan bidang pertahanan ini, dalam kaitannya dengan TN!, berlanjut pada Pemerintahan Megawati Sukamoputri. Perlu dicatat di sini bahwa sejak Pemerintahan Abdurrahman Wahid, jabatan Menteri Pertahanan, yang sejak tahun 1959 selalu dipegang oleh perwira tinggi TNI, maka jabatan tersebut, di samping jabatan Gubemur Lembaga Pertahanan Nasional (Lemhannas), dipegang oleh orang sipil. Hal lain yang juga patut dicatat, adalah, pada masa Pemerintahan Megawati Sukamoputri, pengangkatan jabatan Panglima TNI dan Kepala Staf TNI-AD kelihatannya lebih didasarkan pada pertimbangan non-military politics, yaitu masing-masing dipercayakan kepada personil perwira tinggi TNI yang dikenal profesional, yakni masing-masing kepada Jenderal TNI-AD Endriartono Sutarto dan Jenderal TNIAD Ryamizard Ryacudu. Pada masa lalu, sebelum era reformasi, khususnya pada masa Pemerintahan Suharto, dua jabatan kemiliteran penting tersebut, di samping jabatan-jabatan lain seperti Panglima Komando Strategis Angkatan Darat (Kostrad) dan Komandan Komando Pasukan Khusus (Kopassus), atau jabatan territorial, seperti Panglima Komando Daerah Militer (Pangdam) untuk tingkat Propinsi, pengangkatannya nampak lebih banyak atas dasar pertimbangan militarypolitics. ${ }^{23}$

\footnotetext{
22 Yahya A. Muhaimin, "Pembinaan Bidang Pertahanan Indonesia", dalam Pidato Pengukuhan Jabatan Guru Besar Pada Fakultas IImu Sosial dan IImu Politik, Universitas Gadjah Mada (28 September 2005), hal. 11-12.

${ }^{23} \mathrm{Ibid}$, hal. 12.
} 
Pada tahun 2004, aturan soal supremasi sipil atas tentara diperkuat dalam Undang-Undang 34/2004 tentang TNI. UU ini menyebutkan bahwa "TNI dibangun dan dikembangkan secara profesional sesuai kepentingan politik negara yang mengacu pada nilai dan prinsip demokrasi, supremasi sipil, hak asasi manusia."24 Dengan UU itu, militer menjadi kehilangan fungsi sosial-politiknya. Mereka tidak lagi dapat merangkap menjadi pejabat ataupun menguasai suatu bisnis secara langsung. Struktur ABRI pun dirombak menjadi dua yaitu Polisi yang bertugas menjaga keamanan dan TNI yang bertugas menjaga pertahanan negara. Pemisahan tersebut secara langsung membuat militer tidak lagi diperbolehkan mencampuri urusan sipil.

\section{Pasca-Reformasi TNI}

Pertanyaannya kemudian adalah apa yang terjadi setelah reformasi TNI dilakukan? Sayangnya jawaban untuk pertanyaan itu adalah kemunduran. Sebab kepentingan militer pada bidang ekonomi-politik tidak serta merta ikut terhapus. Seperti halnya dengan kepentingan yang dimiliki oleh kroni-kroni Orba, mengakarnya kepentingan ekonomi-politik militer sejak era Orba membuatnya sulit untuk dihapuskan. Perubahan hukum yang terjadi sejak Reformasi rupanya hanya mengubah dinamika kekuasaan ekonomi dan politik yang dilakukan oleh militer. Sebelum Reformasi 1998, negara memberikan legitimasi penuh terhadap Dwifungsi militer sehingga mereka mampu berkuasa secara terbuka. Namun saat ini, penghapusan Dwifungsi secara legal membuat militer harus menggunakan cara lain untuk tetap mempertahankan kepentingannya. Itulah sebab, peran politik militer pasca reformasi tetap penting. Presiden, dari BJ Habibie hingga Susilo Bambang Yudhoyono, menyadari bahwa membangun dukungan yang kuat dari militer adalah suatu keharusan dalam mempertahankan kekuasaan mereka. ${ }^{25}$

24 Lihat "Kemenangan dan Kekalahan Supremasi Sipil", https://tirto.id/kemenangan-dankekalahan-supremasi-sipil-cxWa

${ }^{25}$ Lihat Leonard C. Sebastian, "Susilo Bambang Yudhoyono and His Generals", dalam Policy Brief, No 1 (Singapore: S. Rajaratnam School of International Studies, 2007). Tulisan ini bisa diakses dalam https://www.rsis.edu.sg/wpcontent/uploads/2014/07/PB070101_Susilo_Bambang_Yudhoyono_and_Generals.pdf 
Itu artinya Dwifungsi tetap eksis meski ada upaya untuk melakukan reformasi TNI. Indikasi bertahannya Dwifungsi itu bisa dilihat dalam laporan Indonesian Corruption Watch. Dalam laporan itu, ICW menemukan bahwa militer kini masih mengurusi urusan sipil dengan berbisnis melalui tiga cara, yaitu bisnis informal, bisnis ilegal, dan koperasi atau yayasan. Bisnis informal dalam bentuk penempatan personel TNI ke perusahaan juga melibatkan TNI sebagai institusi, kesatuan maupun anggota TNI. Bisnis ilegal hanya melibatkan individu dan kesatuan, secara institusi TNI tidak melakukannya. Padahal, UU No. 34 tahun 2004 tidak membedakan antara bisnis ilegal dan formal. Pemerintah seakan-akan lepas tangan, karena menganggap jenis bisnis ilegal dan formal tidak sesuai dengan definisi reformasi militer. Sementara itu, bisnis formal dalam bentuk yayasan dan koperasi melibatkan institusi TNI, kesatuan seperti Kopassus dan individu. ${ }^{26}$

Yayasan dan koperasi sendiri dikategorikan sebagai "kepemilikan tidak langsung" sehingga cukup direstrukturisasi dan tidak diambil alih oleh negara. Sementara itu, bisnis yang dimiliki oleh militer secara langsung perlu diserahkan kepada negara. Akan tetapi, TNI menyatakan bahwa tidak terdapat kepemilikan bisnis secara langsung. Nampaknya, bisnis yang terdaftar pada tahun 2008 dimasukkan ke dalam struktur baru perusahaan yang dijalankan secara legal oleh koperasi. Perubahan ini tercermin dalam peningkatan unit "bisnis' pada tahun 2011 dengan 1.301 koperasi dan lebih dari 13 yayasan. ${ }^{27}$

Menurut laporan Human Rights Watch (2006), yayasan dan koperasi tetap dipertahankan oleh militer karena kurangnya anggaran dari pemerintah untuk memenuhi kesejahteraan prajurit. Rendahnya anggaran menyebabkan gaji prajurit menjadi sangat rendah dan hanya cukup untuk memenuhi setengah dari biaya minimum yang dibutuhkan militer. Akibatnya, militer merasa perlu untuk melakukan kegiatan perekonomian. Menteri Pertahanan Juwono Sudarsono, menyatakan pada tahun 2007, “Anggaran operasi pemerintah untuk TNI masih

\footnotetext{
${ }^{26}$ Lihat bahasannya dalam Olivia Prastiti dan Matthew Alexander, "Dwifungsi dan Transformasi Bisnis Militer Pasca Reformasi”, http://www.balairungpress.com/2018/11/dwifungsi-dantransformasi-bisnis-militer-pasca-reformasi/

${ }^{27}$ Ibid.
} 
sangat rendah, jadi untuk belanja operasi pertahanan dan keamanan, institusi militer harus mendanai sendiri dengan aktivitas bisnis". ${ }^{28}$

Akan tetapi, berdasarkan pemeriksaan keuangan BPK banyak bisnis TNI yang nyaris tidak menyumbang apapun setelah puluhan tahun penyelewengan dan korupsi (Human Rights Watch, 2010). Yayasan dan koperasi militer dikisar memiliki aset kotor sebesar Rp 3.2 trilyun dan aset bersih Rp 2.2 trilyun pada akhir tahun 2007. Aktivitas bisnis ini meraup laba Rp 268 milyar pada tahun yang sama. Ini belum termasuk upah jasa keamanan, sewa tanah dan bangunan, beking perusahaan yang terlibat kriminalitas dan korupsi. Namun, bisnis-bisnis tersebut cenderung tidak digunakan untuk kesejahteraan prajurit. Laporan Human Rights Watch (2006) menyatakan bahwa bisnis militer menjadi sumber keuangan bagi jenderal dan tidak menaikkan taraf hidup prajurit di daerah. Artinya, alasan yang mendukung keberadaan bisnis militer tidak dapat dibenarkan. Alih-alih menyejahterakan prajurit, bisnis militer hanya menjadi bagian dari kepentingan ekonomi-politik elit militer. ${ }^{29}$

Tak berhenti sampai disitu. Upaya untuk melanjutkan peran politik militer terus berlanjut di era pemerintahan Joko Widodo (Jokowi). Uniknya, meski Presiden Jokowi pada dasarnya asing dengan lingkaran kekuasaan tradisional di Jakarta, namun kebutuhan untuk memasukkan kekuatan militer dalam politik justru makin menguat. Sebagai seorang mantan pedagang furnitur tanpa latar belakang militer dan tidak termasuk dalam keluarga politik terkemuka, Jokowi membangun dari awal basis kekuatan politiknya dalam politik oligarki Indonesia. ${ }^{30}$ Dengan infrastruktur yang tak tertandingi di seluruh negeri dan kurangnya pengekangan birokrasi yang dikenakan pada saat itu, melibatkan militer adalah pilihan politik yang paling strategis bagi Jokowi. ${ }^{31}$

\footnotetext{
${ }^{28}$ Ibid.

29 Ibid.

${ }^{30}$ Ulasan yang sangat baik tentang ini, lihat Burhanuddin Muhtadi, "Jokowi’s First Year: A Weak President Caught between Reform and Oligarchic Politics," dalam Bulletin of Indonesian Economic Studies Vol. 51, no. 3 (2015), hal. 349-368.

${ }^{31}$ Periksa Stanley A. Weiss, "A Dangerous Game of Military Politics in Indonesia," dalam HuffPost, 14 Desember 2015, http://www.huffingtonpost.com/stanley-weiss/a-dangerous-game-of-milit_ b_8806936.html.
} 
Maka sejak hari pertama di kantor kepresidenan pada 2014, Jokowi justru "memfasilitasi" kebangkitan kembali TNI dalam politik Indonesia kekinian; sejumlah pensiunan jenderal Angkatan Darat dipilih untuk duduk di kabinet. Jokowi bahkan mendirikan pos baru, Kepala Staf untuk Presiden Jenderal (Purn.) Luhut Panjaitan, yang telah memainkan peran penting dalam membimbing dan membersihkan kekacauan yang dibuat oleh presiden yang tidak berpengalaman. Belakangan Luhut dijadikan oleh Jokowi sebagai Menteri Koordinator Bidang Kemaritiman Indonesia. Jokowi juga menunjuk pensiunan jenderal lain untuk mengisi posisi Menteri Pertahanan, Ryamizard Ryacudu.

Bahkan salah seorang analis menegaskan, diera Jokowi lebih banyak tokoh militer sekarang "menonjol di posisi sipil atas" jika dibandingkan dengan saat masa transisi Indonesia ke demokrasi pada tahun 1998. ${ }^{32}$ Di luar kabinet, Jokowi juga tanpa henti mencoba memperluas peran militer. Di tengah kritik, Jokowi tetap memerintahkan TNI untuk membantu Kementerian Pertanian demi mencapai kecukupan pangan dan menstabilkan harga makanan pokok. Otorisasi pemerintah untuk meningkatkan peran TNI dalam operasi kontra-terorisme, terutama di Poso, juga tidak membantu mengesampingkan militer dari area keamanan dalam negeri. Ketika militer menandatangani Nota Kesepahaman (MoU) dengan kementerian dan perusahaan negara untuk penyediaan layanan keamanan, Jokowi malahan menutup mata. TNI kini sedang mencoba menguji medan politik dengan melihat sejauh mana ia dapat mendorong otoritasnya dan memperluas peranannya di bidang-bidang yang bukan menjadi perhatian utama militer. ${ }^{33}$

Hingga tahun 2018, militer telah memiliki lebih dari 30 nota kesepahaman dengan kementerian dan lembaga negara lainnya yang memungkinkan mereka untuk mengurusi ranah sipil. Contohnya seperti telah disebutkan di atas bahwa nota kesepahaman dengan Kementrian Pertanian di tahun 2015 menyebutkan militer ikut dilibatkan dalam kegiatan pertanian masyarakat di desa-desa. Selain itu, terdapat

\footnotetext{
${ }^{32}$ Lihat Emirza Adi Syailendra, "Under Suharto's Shadow: Jokowi and the Indonesian Military," dalam Foreign Affairs, 2015, https://www.foreignaffairs.com/articles/indonesia/2015-08-12/undersuhartos-shadow.

${ }^{33}$ Lihat "The Expanding Role of the Indonesian Military", dalam IPAC Report, No. 19, 25 Mei 2015), http://file.understandingconflict.org/file/2015/05/IPAC_19_Expanding_Role_of_TNI.pdf
} 
seorang jenderal aktif yang mencalonkan diri pada Pilkada 2018. Meskipun akhirnya jenderal tersebut kemudian mengundurkan diri dari jabatannya setelah terpilih menjadi calon kepala daerah. Tidak hanya itu, militer juga masuk ke ranah pendidikan dengan menyelenggarakan pemutaran film tentang Gerakan 30 September di sekolah-sekolah. Beberapa hal tersebut menunjukkan bahwa militer masih tertarik untuk mengurusi hal-hal di ranah sipil. ${ }^{34}$

Hal ini telah diakui oleh presiden Jokowi yang berniat menerapkan kebijakan penempatan perwira TNI aktif di sejumlah lembaga sipil. Ini dilakukan Jokowi sebagai solusi untuk memberikan pekerjaan kepada perwira-perwira menengah dan tinggi TNI yang menganggur atau dalam kondisi non-job. Untuk mengatasi hal tersebut, rencana restrukturisasi TNI pun dianggap sebagai hal yang mendesak. Dalam pertemuan Presiden Jokowi dengan perwira-perwira TNI pada awal 2019, persoalan ini menjadi salah satu yang dibahas. Jokowi kemudian menegaskan bahwa akan ada ruang jabatan baru untuk perwira-perwira TNI tersebut. Beberapa waktu berselang, Panglima TNI Hadi Tjahjanto turut buka suara terkait rencana restrukturisasi dan pemberian ruang jabatan tersebut. Tak hanya berbicara tentang restrukturisasi internal TNI, mantan KSAU tersebut menyebut bahwa ada rencana untuk menempatkan perwira-perwira TNI di Kementerian dan Lembaga.

Setelah Jokowi terpilih kembali menjadi presiden untuk kedua kalinya pada 2019, upaya untuk melibatkan TNI dalam persoalan sipil dan non perang tetap dilakukan. Dalam kasus terbaru, misalnya, Jokowi dinilai telah membuat keputusan keliru karena telah melibatkan TNI secara penuh dalam menangani merebaknya wabah COVID-19 di Indonesia. Hal ini bisa dilihat dari keberadaan sejumlah personel militer aktif pada Gugus Tugas Penanganan COVID-19, pembentukan tim khusus di bawah Komando Gabungan Wilayah Pertahanan (Kogabwilhan), dan pelaksanaan berbagai operasi mitigasi di tingkat pusat maupun daerah. Pada satu sisi, berbagai kontribusi prajurit TNI yang selama ini bertugas tentu tidak dapat

\footnotetext{
${ }^{34}$ Lihat Olivia Prastiti \& Matthew Alexander, "Dwifungsi dan Transformasi Bisnis Militer Pasca Reformasi”, http://www.balairungpress.com/2018/11/dwifungsi-dan-transformasi-bisnis-militerpasca-reformasi/
} 
dikesampingkan dan layak diapresiasi. Namun pada sisi lain, dinamika pelibatan TNI itu tetap harus terukur serta sesuai dengan ketentuan hukum dan tata cara pelibatan di dalam negara demokrasi. ${ }^{35}$

Ketentuan pelibatan militer untuk operasi militer selain perang (OMSP) memang telah diatur dalam pasal 7 ayat 2 dan 3 UU TNI No. 34/2004. Di dalamnya, dijelaskan bahwa militer bisa melakukan 14 jenis operasi militer selain perang yang salah satunya adalah membantu kepolisian dan pemerintah. Namun UU tersebut juga menyebutkan bahwa pelibatan militer baru dapat dilakukan jika ada keputusan politik negara. Adapun keputusan politik negara yang dimaksud adalah kebijakan politik pemerintah bersama-sama DPR yang dirumuskan melalui mekanisme hubungan kerja antara pemerintah dan DPR, seperti rapat konsultasi dan rapat kerja sesuai peraturan perundang-undangan (penjelasan Pasal 5 UU TNI). ${ }^{36}$

Namun, masalahnya adalah skema pada UU TNI ini tidak digunakan oleh pemerintah dalam melibatkan militer untuk mengawal fase kenormalan baru. Dengan kata lain, pelibatan militer dalam tim gabungan TNI-Polri tidak didasarkan atas keputusan politik negara. Terlepas dari persoalan legal-formal, pengabaian terhadap keputusan politik negara juga mengandung masalah lain. Hal ini menyebabkan tidak adanya acuan ataupun skema yang dapat digunakan untuk mengukur pelibatan militer dalam melaksanakan tugas selain perang. Dalam konteks itu, Pusat Penelitian Politik LIPI menyebut tiga potensi permasalahan yang bisa muncul. ${ }^{37}$

Pertama, tidak ada kejelasan sampai kapan militer akan terlibat dalam tugas pendisiplinan warga. Apabila indikator yang digunakan adalah 'kenormalan baru', maka ini mengindikasikan bahwa militer bisa selamanya terlibat dalam tugas-tugas pendisiplinan warga. Apabila berlangsung secara berlarut-larut, tentu hal ini akan menimbulkan kerancuan antara fungsi pertahanan, keamanan, dan penegakan hukum yang dicampuradukkan menjadi satu. Padahal, secara prinsip pelibatan

\footnotetext{
${ }^{35}$ Lihat "TNI dan Kenormalan Baru”, http://politik.lipi.go.id/kolom/kolom-2/politik-nasional/1403tni-dan-kenormalan-baru?fbclid=IwAR34WfTq1Nt4h73ef3dncxsnTWYMq4NV3ze1ZDsTTfWZIqpn4 3 BF891G-Q ${ }^{36}$ Ibid.

${ }^{37}$ Ibid.
} 
militer dalam operasi militer selain perang itu sifatnya ad hoc atau sementara, sehingga perlu ada batasan waktu yang jelas di dalam kebijakan yang dibuat oleh pemerintah sampai kapan militer akan dilibatkan. Sulit dibenarkan apabila ada pengerahan militer dalam operasi selain perang yang tidak jelas ukuran waktu operasinya karena itu akan menjadi masalah baru bagi TNI sendiri dan bagi kehidupan demokrasi.

Kedua, tidak ada penjelasan atas urgensi atau alasan pelibatan militer. Hal ini menyebabkan sulitnya menilai proporsionalitas pelibatan yang diperlukan. Pengerahan 340.000 personel TNI-Polri dalam misi mengawal kenormalan baru sesungguhnya menunjukkan angka yang cukup fantastis. Meski pemerintah Indonesia tidak merilis jumlah pasti personel militer yang dikerahkan, namun angka tersebut jauh lebih besar dibandingkan negara-negara lain. Amerika Serikat, misalnya, total jumlah personel militer yang dikerahkan sekitar 55.000 untuk berbagai misi (tidak hanya satu misi). Begitu pula di Inggris, jumlahnya pernah mencapai 20.000 namun baru-baru ini dikurangi hingga 7.500 personel menjelang fase kenormalan baru di negara tersebut. Dalam konteks itu, tentu muncul pertanyaan mengapa pemerintah membutuhkan begitu banyak personel militer di lapangan?

Ketiga, tidak ada kejelasan perhitungan atas dampak dari tugas pengawalan ini terhadap kesiapan militer. Pengerahan pasukan secara besar-besaran untuk mengawal fase kenormalan baru sedikit banyak akan berdampak pada kesiapan militer dalam mengemban tugas utama mereka. Fokus, waktu, energi, dan pelatihan yang dibutuhkan untuk menjaga kesiapan perang menjadi terdistraksi dalam menghadapi pandemi ini. Mengingat dinamika ancaman yang bisa hadir kapanpun, tentu kesiapan militer perlu terus dijaga. Perhitungan terhadap dampak kesiapan militer dalam mengemban tugas utamanya untuk menghadapi perang sejatinya tetap perlu dipertimbangkan.

Bagi Pusat Penelitian Politik LIPI. berbagai potensi permasalahan itu sesungguhnya menunjukkan bahwa rencana pelibatan militer dalam fase kenormalan baru belum dibarengi dengan indikator yang rigid dan terukur. Dalam konteks itu, pemerintah perlu meninjau ulang persiapan pelibatan militer dalam 
kenormalan baru. Pelibatan militer memang mungkin dilakukan, namun hendaknya hal itu dilakukan dengan pertimbangan yang matang terhadap aspek mitigasi krisis, dampak terhadap masyarakat, dampak terhadap profesionalisme militer itu sendiri, serta kesesuaian dengan ketentuan hukum. ${ }^{38}$

Di satu sisi, memberikan ruang-ruang gerak baru untuk perwira TNI boleh jadi merupakan hal penting. Akan tetapi, memberikan porsi lebih kepada TNI untuk jabatan sipil di kementerian dan lembaga sipil tentu saja akan membuat pegiat demokrasi mempersepsikan langkah Jokowi dan lingkaran TNI-nya ini sebagai upaya untuk mengembalikkan Dwifungsi ABRI. Apalagi Presiden Jokowi diketahui mendukung amandemen yang diusulkan untuk UU TNI tahun 2004. Dengan demikian, perkembangan terakhir ini menunjukkan bahwa militer rupanya masih memiliki peran penting dalam politik sehari-hari dan keterlibatannya dalam kegiatan sipil belum berkurang sama sekali.

\section{KESIMPULAN}

Dapat dikatakan bahwa Dwifungsi angkatan bersenjata di Indonesia berevolusi dan mencapai puncaknya pada era Orba. Di era ini peran sosial-politik ABRI menjadi sangat dominan dalam segala aspek kehidupan masyarakat. Namun setelah rezim Orba runtuh pada 1998, dengan krisis moneter akut yang menyertainya, masyarakat Indonesia menuntut negara ini menjadi demokratis seutuhnya. Akibatnya, Dwifungsi ABRI pun ditinggalkan.

Tapi seiring waktu berjalan, upaya untuk mengembalikan Dwifungsi tetaplah kuat. Kini TNI bahkan sudah mulai mengisi jabatan-jabatan sipil. Ini tentu saja merupakan langkah mundur dan membuat Indonesia seakan kembali ke masa otoriter. Padahal, Samuel Huntington pernah mengingatkan bahwa militer harus kembali ke barak sebagai prasyarat bagi demokrasi yang sehat. ${ }^{39}$ Jika merujuk pada pendapat Huntington ini, maka rencana pemerintahan Jokowi untuk memberikan ruang jabatan bagi militer di kementerian dan institusi sipil lainnya bertentangan

\footnotetext{
38 Ibid.

${ }^{39}$ Lihat Samuel Huntington, The Soldier and the State: The Theory and Politics of Civil-Military Relations, (Cambridge, Mass: Belknap Press of Harvard University Press, 1957).
} 
dengan semangat demokrasi dan jika dibiarkan akan menjurus kepada sikap otoritarianisme. Tom Power di New Mandala menyindirnya dengan istilah, "Jokowi's Authoritarian Turn". ${ }^{40}$

Jika ini dibiarkan, maka reformasi sektor keamanan sebagai bagian dari reformasi TNI akan menemui kegagalan. Sebab tanpa reformasi itu, TNI akan menjadi seperti apa yang disebutkan oleh Laurie Nathan sebagai destroy the democratic project. ${ }^{41}$ Tentu kami tidak menginginkan hal itu terjadi, dan berharap TNI tetap pada sikapnya yang demokratis dan mengubur dalam-dalam keinginan untuk mengembalikkan Dwifungsi.

\section{DAFTAR PUSTAKA}

Crouch, Harold, The Army and Politics in Indonesia, (Itacha: Cornell University Press, 1978).

, Militer dan politik di Indonesia, (Jakarta: Sinar Harapan, 1986)

Huntington, Samuel P., The Soldier and the State: The Theory and Politics of CivilMilitary Relations, (Cambridge, Mass: Belknap Press of Harvard University Press, 1957).

"Kemenangan dan Kekalahan Supremasi Sipil”, https://irto.id/kemenangan-dankekalahan-supremasi-sipil-cxWa

Muhaimin, Yahya A., Perkembangan Militer dalam Politik di Indonesia, 19451966, (Yogyakarta: Gadjah Mada University Press, 1982).

., "Pembinaan Bidang Pertahanan Indonesia", dalam Pidato Pengukuhan Jabatan Guru Besar Pada Fakultas Ilmu Sosial dan Ilmu Politik, Universitas Gadjah Mada (28 September 2005).

Muhtadi, Burhanuddin, “Jokowi's First Year: A Weak President Caught between Reform and Oligarchic Politics," dalam Bulletin of Indonesian Economic Studies, Vol. 51, no. 3 (2015).

Nasution, A.H., Toward the People's Army, (Jakarta: C.V. Delegasi, 1964).

\footnotetext{
40 Tom Power, "Jokowi's Authoritarian Turn", https://www.newmandala.org/jokowisauthoritarian-turn/

${ }^{41}$ Nathan, Lauri, "Obstacles to Security Sector Reform in New Democracies", https://www.berghoffoundation.org/fileadmin/redaktion/Publications/Handbook/Dialogue_Chaptersdialogue2_ nathan. pdf
} 
Nathan, Lauri, "Obstacles to Security Sector Reform in New Democracies", https://www.berghof-foundation.org/fileadmin/redaktion/Publications/ Handb ook/Dialogue_Chaptersdialogue2_nathan. Pdf

Prastiti, Olivia \& dan Matthew Alexander, "Dwifungsi dan Transformasi Bisnis Militer Pasca Reformasi”, http://www.balairungpress.com/2018/11/dwifungsi-dan-transformasibisnis-militer-pasca-reformasi/

Said, Salim, Genesis of Power: General Sudirman and the Indonesian Military in Politics, 1945-49, (Singapore: Institute of Southeast Asian Studies, 1991).

Sebastian, Leonard C., "Susilo Bambang Yudhoyono and His Generals", dalam Policy Brief, No 1 (Singapore: S. Rajaratnam School of International Studies, 2007),https://www.rsis.edu.sg/wpcontent/uploads/2014/07/PB070101_Susilo_Bambang_Yudhoyono _and_Generals.pdf

Singh, Bilveer, Dwifungsi ABRI: Asal-usul, Aktualisasi dan Implikasinya bagi Stabilitas dan Pembangunan, (Jakarta: Gramedia Pustaka Utama, 1996).

Soedibyo, "Armed Forces of the Republic of Indonesia: Prospects for the 1990s", dalam The Indonesian Quarterly, Vol. 18, No. 3 (Kwartal ke-3, 1990).

Sundhaussen, Ulf, Politik Militer Indonesia, 1945-1967: Menuju Dwifungsi ABRI, (Jakarta: LP3ES, 1987).

Syailendra, Emirza Adi, “Under Suharto's Shadow: Jokowi and the Indonesian Military," dalam Foreign Affairs, 2015, https://www.foreignaffairs.com/ articles/indonesia/2015-08-12/under-suhartos-shadow.

“The Expanding Role of the Indonesian Military", dalam IPAC Report, No. 19, (25 Mei 2015), http://file.understandingconflict.org/file/2015/05/IPAC_19 Expan ding Role of TNI.pdf

"TNI dan Kenormalan Baru", http://politik.lipi.go.id/kolom/kolom-2/politiknasional/1403-tni-dan-kenormalan-baru?fbclid=IwAR3-4WfTq1Nt4h73ef 3dn xsnTWYMq4NV3ze1ZDsT TfWZ Iqpn43BF891G-Q

Tom "Jower, “Jokowi's Authoritarian Turn", https://www.newmandala.org/jokowis-authoritarian-turn/

Weiss, Stanley A., "A Dangerous Game of Military Politics in Indonesia," dalam HuffPost, 14 Desember 2015, http://www.huffingtonpost.com/stanleyweiss/a-dangerous-game-of-milit_b_8806936.html. 